\title{
RESISTANCE RETOLD: HISTORICAL AND MYTHICAL NARRATIVES IN PLAYS BY ROMERO, RESINO, PASCUAL AND DE PACO SERRANO
}

\author{
RECONTANDO LA RESISTENCIA: NUEVAS NARRATIVAS \\ MÍTICAS E HISTÓRICAS EN EL TEATRO DE ROMERO, \\ RESINO, PASCUAL Y DE PACO SERRANO
}

\author{
Helen FREEAR-PAPIO \\ College of the Holy Cross, Worcester, Massachusetts \\ hfreear@holycross.edu \\ orcid.org/0000-0002-4117-6809
}

\begin{abstract}
In this article we will look at a small but cohesive sample of plays by female dramatists of democratic Spain from the 1980's to the present, in which the dramatic retelling of history and myth has evolved in time as it accompanied the emergence of stronger female narratives. We will focus on plays that feature female protagonists whom we think we already know from history or mythology and who confront culturally predominant male narratives. In each case, the playwright offers her characters a unique opportunity to deconstruct and re-write these stories, or even to demythify and re-inscribe myth. These writers emphasize the credibility of their female characters as they urge their spectators to question the legitimacy of traditional patriarchal roles for women and to look beyond a purely masculine point of view to a more pertinent and comprehensive view of the problems that exist in the world outside the theater.
\end{abstract}

Keywords: myth, history, woman-authored theater, female characters, resistance.

\section{Resumen}

En este artículo veremos una muestra pequeña pero coherente de obras de dramaturgas de la España democrática, desde los años 80 hasta la actualidad, en las que se ve una relectura de la historia y del mito. Nos centraremos en las obras protagonizadas por mujeres que ya reconocemos de la historia o de la mitología y veremos cómo estas

Feminismo/s 30, diciembre 2017, pp. 47-68

Los contenidos de la revista se publican bajo una licencia de Creative Commons Reconocimiento 4.0 Internacional (CC BY 4.0) 
figuras se enfrentan a las narrativas masculinas predominantes. En cada caso, la dramaturga ofrece a sus personajes una oportunidad única para deconstruir y re-escribir estas historias, o incluso para desmitificar y luego re-escribir unos mitos. Estas escritoras enfatizan la credibilidad de sus personajes femeninos mientras piden a su público que cuestione la legitimidad de viejos papeles patriarcales para mujeres, que mire más allá de un punto de vista puramente masculino y que proponga una visión más pertinente y completa de los problemas que existen en el mundo fuera del teatro.

Palabras clave: mito, historia, teatro de mujer, personajes femeninos, resistencia. 


\section{INTRODUCTION}

From the vantage point of 2017, we can look back over the last three decades of works by female dramatists in democratic Spain with a degree of historical and literary perspective. With a critical eye, we can make out a cementing of literary generations, a progression of developing personalities and a flourishing of themes, always underpinned by the constant, keen awareness of the importance of giving women a voice. This paper will look at a small, but cohesive, sample of plays from the 1980's to the present in which the dramatic retelling of history and myth has evolved in time as it accompanied the emergence of stronger female narratives. Generally, we shall focus on plays that feature female protagonists who confront culturally predominant male narratives. Within that group, we will consider more specifically the appearance on stage of figures whom we think we already know from history or mythology. In each case, the dramatist presents to her characters a peculiar opportunity to deconstruct and rewrite those histories, or even to demythify and then reinscribe our own myths. These playwrights emphasize the believability of their female characters as they ask their audiences to reevaluate the legitimacy of age-old patriarchal roles for women; meanwhile they offer thoughtful meta-commentaries on the nature and power of women's writing.

We shall begin this study by looking at three plays, two written by Concha Romero and one by Carmen Resino, dramatists who belong to the first generation of female playwrights of democratic Spain. Both writers chose to reclaim and stage the lives of two famous queens, Isabel I of Castile and Elizabeth I of England. In Romero's 1988 play, Las bodas de una princesa, we meet a young princess Isabel who stands up to the nobles seeking to usurp her power as they consolidate their own. By the end of the play, we clearly hear the strong voice of the future queen who will unite Spain. In Juego de reinas, published just one year later, Romero further emboldens her female characters. The audience witnesses a series of intimate and contentious conversations between Isabel and her daughter, two women who completely disagree about how a woman should rule. Carmen Resino picks up the gauntlet of recovering lost female voices laid down by Romero in her Los eróticos sueños de Isabel Tudor (1992), 
a play that can now be considered a pivotal, transitional work in Spanish women's theater. In terms of style, Resino cast aside realism and turned to complex dramatic techniques more commonly associated with the so-called second generation of female dramatists. Through flashbacks, dream sequences and metatheater, she frees Elizabeth I from the restrictive persona of the cold Virgin Queen and reveals to the audience a woman who, having learned to embrace her until then repressed sexuality, succeeds in balancing her public duties with her private desires.

Las voces de Penélope (1998) and Polifonía (2000), respectively, are among the early works of Itziar Pascual and Diana M. de Paco Serrano, two prolific members of the second generation of female dramatists. The very structure of these plays immediately sets them apart from their predecessors. Characterized by out-of-sequence events and constantly shifting and dividing characters, these works form a sort of puzzle to be assembled by the audience. De Paco and Pascual here prefer myth to history in the exploration of female roles because they understand how its symbolic, cyclical nature creates a fertile environment for the discussion of timeless, universal themes. In fact, both choose to retell the story of Penelope, the archetypal passive and obedient wife of ancient legend, who waits dutifully and loyally for Ulysses, her heroic husband, to return from war. Pascual gives voice to mythical and modern-day Penelopes to confirm female passivity as an unhealthy, gendered role that women have been conditioned to play. De Paco's Penelope, by contrast, is in the company of a trio of other famous heroines, Medea, Clytemnestra and Phaedra, each of whom must come to terms with a violent past by creating an authentically personal version of her infamous story. By demythifying the heroes and elevating female discourse, both authors offer to their modern-day audience a new woman-authored, gynocentric mythology.

Lastly, we will look at two of Pascual's and de Paco's more recent works. Both authors continue to give voice to famous historical and mythical women but they also expand the focus of their plays to include a more pointed criticism of today's society. Pascual's Variaciones sobre Rosa Parks (2007), for example, mixes history and myth together. On the one hand, it is the untold biography of a dying and senile Rosa Parks, while on the other, it is a modern retelling of Antigone by Sophocles. Pascual's decision to split Rosa Parks into two distinct and embattled characters allows the audience to witness a more honest assessment of certain events that energized the civil rights movement. Pascual uses one woman's moment of defiance, of civil disobedience, to criticize many more of modern society's failings, including poverty, apathy and racism. In her Casandra (2016), de Paco returns to a mythological world, one 
that nevertheless bears a strong resemblance to modern times, to challenge the traditional myth of Cassandra, who puts on stage an alternate version of her life story, equally as believable and equally as compelling as that of the original male version of her myth. In her story, Apollo is the villain, the monster responsible for the death and destruction caused by the Trojan War. Casandra should be read as a treatise against fake news and propaganda that still leads nations into war in our modern world. It also reminds us just how difficult it is to uncover the truth and how much harder it is for women to be heard and respected when they are the ones who speak truth to power.

\section{REALISTIC RETELLINGS OF HISTORY}

Romero's Las bodas de una princesa (1988) and Juego de reinas o razón de estado (1989) present Isabel during two distinct moments of her life. In the former, she is an adolescent princess caught in the midst of a power-struggle for sucession to the throne of Castile, while in the latter she is an elderly queen whose steady, forceful presence is juxtaposed with the increasingly unhinged emotional fragility of her daughter, Juana la Loca. Las bodas is realistic in style and presents all events in chronological order. Isabel's failure to appear until the third scene highlights how little volume her voice has in the patriarchal world that she inhabits. The men in power strategize and scheme about Isabel's political value, using her as a pawn as they decide her marriage plans. Despite the force of power-hungry men objectifying and monetizing the young Princess, she remains nobly defiant. When we finally do meet Isabel, she is in the privacy of her room, seated by the window, sewing. This wholesome pastime, like spinning, is an unmistakable allusion to premodern femininity and perhaps even a subtle nod to Homer's Penelope who spends years weaving, and unweaving, as she fends off suitors ${ }^{1}$. The question implied by the Homerian connection is whether or not Isabel, too, will give in to self-sacrifice and passive resignation. Her first words indicate that she will not: « ¿ástima que las princesas no podamos casarnos libremente! Siempre son los otros que deciden nuestras bodas» $(1988,23)$. The scene crisply forewarns the audience that this young woman will not be a pushover; she will not sit by submissively while men decide her fate.

Indeed, her conduct in public shows the beginnings of the birth of Isabel I as a savvy political and military leader. She is composed and shows a keen understanding of the importance of her role in the future of Castile. Although

1. Carolyn J. Harris observes that Isabel is «la mujer que espera encerrada, mirando por la ventana y soñando con un futuro incierto» $(1993,22)$.

Feminismo/s 30, diciembre 2017, pp. 47-68 
upset and dismayed to learn that she may be forced to marry the King of Portugal, Isabel hides her emotions and calmly counters the notion with logical reasons why the marriage should not take place. Only back in her room does she collapse into tears and declare that she will never marry him. Isabel's private reaction is that of a "very human and vulnerable young woman whose solutions to problems are still naive, but whose determination suggests promise for further development and eventual triumph» (Podol 30). A similar pattern is followed when the nobles conspire to have her marry one of them so that they may thus control the young princess and appropriate her power. Isabel fights back with intelligence, suggesting to one of the nobles that, «sería una lástima utilizar la boda de una princesa para resolver un conflicto interno cuando hay alianzas con el exterior más convenientes. Está Francia, Inglaterra, Portugal y también Aragón» $(1988,66)$. Isabel is acutely aware of her role in the configuration of history and is determined to make the best decision for her country. She understands that she must balance her public and private identities if she is to be successful in both.

Isabel eventually marries Fernando of Aragon, and her newly-gained political acumen is evident as she negotiates the terms of this union: «y cuide de que mis derechos queden garantizados. Los dos aportamos lo mismo y no quiero ser una reina consorte. En Castilla y Aragón tanto debe mandar él como debo mandar yo. Si no acepta tampoco con él me caso» (72). The message of female empowerment may seem weakened somewhat by the fairytale ending, but there are still many positives to be taken from the play, including the re-appropriation of women's history and the fact that Isabel is cast as an intelligent, albeit emotional, young woman who successfully takes control of her destiny while never ignoring the political ramifications of her actions. «Ha encontrado la forma de dirigir su vida personal y pública a la vez que impone su visión y su punto de vista» $(1993,23)$, to use Harris' phrase.

In Juego de reinas, Romero picks up the queen's story at the end of her life. The more public political intrigue of Las bodas de una princesa is pushed now into the background so that she can squarely focus on the difficult relationship between mother and daughter. Romero not only foregrounds her female protagonists, allowing their view of events to assume unrivaled importance, but also silences the men. In fact, no male voices are heard in this play at all. What political framework does exist in Juego de reinas is built around the transfer of power: Isabel is reaching the end of her life and Juana, her only living child, must be ready to assume the throne. It is not exactly court intrigue that moves her plot, however. Romero wants to shine a light on Juana's madness. The male-dominated version of history is clearly rewritten in the long 
dialogues between mother and daughter, during which it becomes clear that private sacrifices are required to attain and hold on to public power, sacrifices that Isabel accepted for the good of her country. Providing the counterpoint to this position, Juana claims that Isabel's personal sacrifices had been too great and denies that she would ever sacrifice her private life as queen. The mother and daughter represent two extreme positions: Isabel is focused on Spain's future, no matter the personal cost, while Juana, who describes her life as «un cuento de hadas» $(1989,4)$, lives obsessively for her husband. Isabel sees the danger inherent in her daughter's emotional blindness, and tells her, «no esperes que nadie te resuelva los problemas. Debes tener criterios propios y saber imponerlos incluso a tu marido si es necesario. Tú serás la reina. Él sólo rey consorte. No lo olvides nunca» (20). Her advice falls on deaf ears as Juana's personal happiness and eventually, her sanity, will be destroyed as she allows herself to be governed only by her emotions. Isabel's life of personal sacrifice for political gain, the repeated triumph of reason over emotion, will be exposed as a politically brilliant yet personally destructive strategy. Taken together, the plays show an evolution in Romero's retelling of a famous life. From a young age Isabel has learned to be acutely aware of all that rests on her shoulders, but, despite her political successes, the end of Juego de reinas reveals the often hidden personal cost. Isabel sums up her life this way: «cumplí mi destino como un hombre aunque haya sufrido como una mujer» (47).

\section{A BRIDGE BETWEEN GENERATIONS.}

At first glance, Romero's plays appear to share a lot, both structurally and thematically, with Los eróticos sueños de Isabel Tudor (1992). Like Romero's Isabel, Resino's Elizabeth faces problems that arise from being a powerful female figure in a male-dominated world. However, in place of the powerful realism and linear plot progression used by Romero, Resino utilizes a much more complex dramatic style. Chronological time is broken up by flashbacks and dream sequences and objective realism is regularly thwarted by duplicitous and disguised characters as well as by the injection of metatheatrical commentary. In retrospect, we can see that Resino is constantly distancing herself from Romero's earlier realistic model and tending towards the much more complex, postmodern techniques of the second generation of dramatists.

Los eróticos sueños' revision of patriarchal history is evident from its very title. That Elizabeth I should have erotic dreams is a far throw from the traditional image of the frigid, virginal queen. The subtitle, La quimera y lo util, and Resino's comments following the list of dramatis personae serve to signal to the spectator that all is not as it seems: 
Sin embargo, todos estos personajes, al igual que María-Ana, no son más que desdoblamientos de la reina, que diversificaciones de ese monólogo íntimo en el que se debate: la continua dialéctica entre la obligación y el deseo; la circunstancia histórica y el ser como individuo. (12)

Resino reveals upfront that all the characters presented are projections of Elizabeth's mind and reminds us that we are witnessing one long interior monologue, not a series of dialogues between the queen and other characters. One might assume that this information could help us understand the events that unfold, but the opposite is true. Resino layers fiction upon fiction, juxtaposing dream and reality, until we lose track of the real Elizabeth and are forced to treat «history» subjectively, which is an innovation in itself.

The historical episode that serves as a backdrop for this intimate drama of self-discovery is the English victory over the Spanish Armada in 1588. Cecil, the prime minister, wants Elizabeth to confront increasing Spanish aggression yet he cannot get her to engage with the problems facing her nation. We soon learn that Elizabeth is distracted from her regal duties by her private desires; she is secretly in love with Phillip II of Spain, the protagonist of her erotic dreams. In these dreams, however, Phillip always turns into Elizabeth's nemesis, Sir Francis Drake, causing her to awaken frustrated and irritated. Fantasy and reality become still further intertwined when she receives a message, purportedly from Phillip, inviting her to a clandestine romantic rendezvous. When Phillip is admitted to her quarters, the spectators witness a magnificent play within a play, in which the king and queen flirt, gossip and enjoy erotically charged, intelligent conversation, laden with double-entendres. As the scene progresses, Elizabeth realizes that, just as in her dreams, the man seducing her is again Drake, disguised as Phillip. Nonetheless, she chooses this time to accept Drake's advances in order to spend two more days fulfilling her private erotic desires, which have in this moment obscured her public responsibilities.

The effects of the constant tug of war between Elizabeth's desires and duties are evinced in the juxtaposition of two scenes: one between Elizabeth and María-Ana, her lady in waiting, and the other between the queen and her prime minister, Cecil, who is plainly the voice of reason, of historical reality, of political responsibility and of the patriarchy. His interactions with Elizabeth in and about the public realm provide a frame for the more controversial and intimate discussions between Elizabeth and María-Ana as well as for the love scene between Elizabeth and Phillip/Drake. Ultimately, the audience realizes that the Elizabeth who appears with Cecil seems less convincing, even almost untrustworthy, as if she were merely pretending to be queen. By contrast, the private Elizabeth, the one seen with María-Ana and Phillip/Drake seems to 
be more genuine. These contradictory images enact the illusion/reality dichotomy alluded to in the play's subtitle and force the audience to piece together a richer, more complex and therefore more accurate image of the famous queen.

Initially, María-Ana clearly represents all the emotions that Elizabeth had denied and suppressed in order to become a powerful leader: «es joven, muy bella y sin embargo se parece a Isabel: es como una proyección retrospectiva y en cierto modo equivocada de la reina» (14). María-Ana is the whore and Elizabeth the virgin, but this binary relationship will flip-flop throughout the play, repeatedly putting in doubt the veracity of Elizabeth's traditional image. Elizabeth frequently calls María-Ana a slut and criticizes her inappropriate behavior, yet María-Ana responds to her attacks with brutal honesty, challenging the legitimacy of the queen's chaste public image and forcing her official persona to face the truth about her real, private yearnings. Eventually, Elizabeth will switch roles with María-Ana, and she is acutely aware of doing it: «ite das cuenta, Ana? En este momento tenemos los papeles cambiados: yo debería ser la celestina y tú la virgen» (34). María-Ana is uncomfortable with the transformation in her mistress: «Perdonadme, señora, lo que deseo es que volvamos a nuestros hábitos y, sobre todo, veros como siempre: ¡Fría, distante, con esta realeza tan magnífica!» (46). To this Elizabeth responds, «(Casi para sí)... Y tan engañosa» (46). Emotion has overcome reason, private desires have eclipsed public responsibilities and Elizabeth has become the subject who controls her own drama instead of an object controlled by the norms and exigencies of the patriarchal society, in which she must not only live as a woman, but over which she must also rule. Elizabeth's recognition of the validity of the powerful emotions that she felt in private have given her a sense of power and confidence to return, reinvigorated, to her public role. The play ends with a meeting between Elizabeth and Cecil in which she finally agrees to receive Drake and to fashion a military strategy that will destroy Phillip's hopes of invading England. This decision, of course, will result in the defeat of the Spanish Armada. The last image in the play is an unequivocal admission that Elizabeth's existence as a formidable public figure is due, in part, to the understanding and acceptance of her sexuality. Standing in front of a full-length mirror as she prepares to receive Drake, she exclaims: "(Entre el insulto, la complicidad y el reto.) Isabel Tudor, reina de Inglaterra... jzorra!» (80).

These three historical dramas by Romero and Resino are structured around the push and pull of the public/private dichotomy. The private persona behind the public façade is an image that contrasts with the audience's preconceived notions of these historical figures, notions learned from male-documented versions of history. The revision and reinterpretation of the private processes 
behind famous public events and decisions make for fascinating, thought-provoking theater. Female characters with agency make their voices heard over those of the monstrous din of the status quo: they are new role models for the modern woman to admire and imitate.

\section{HARNESSING THE POWER OF MYTH AND HISTORY: RELLING PENELOPE'S STORY}

With Los eróticos sueños de Isabel Tudor we have left behind the first generation of female Spanish dramatists and are moving on to plays by Itziar Pascual (Las voces de Penélope, 1998) and Diana M. de Paco Serrano (Polifonía, 2000), members of the current (second) generation ${ }^{2}$. Diana de Paco describes the theatrical philosophy of her generation: «en general, se aleja de los parámetros realistas que caracterizaban la dramaturgia de los ochenta y busca en la deconstrucción de la estructura del texto y la fragmentación de las bases tradicionales la expresión de una nueva estética» $(2003,91)$. This new aesthetic can be seen in the use of a variety of complex dramatic styles including fragmented dialogue, out-of-sequence events, deconstruction of memory, role-playing, metatheater, intertextuality and the dissolution of self (Floeck 2004, 191). The audience also assumes a relatively more active role. This style of theater forces each spectator to put together the pieces of the mosaic created on stage, and in so doing, to participate in the creation of meaning $(2004,191)$. Topics common to these two playwrights include myth, gender violence, war, immigration, racism, female identity, the role of women in society and the economic crisis. These pertinent, diverse and highly relevant themes are often presented through the eyes of a female protagonist, one who offers the spectator a new lens through which to view these pressing issues.

In Las voces de Penélope, Pascual tells her story through a complex, multifaceted structure, fractured across twenty scenes ${ }^{3}$ : six of them correspond to Penelope's ancient, mythical world, thirteen take place in the present-day spaces of the other two characters, La mujer que espera and La amiga de Penélope, and the twentieth, which brings the three characters together in a

2. Penelope is the protagonist of both these plays and I would be remiss if I did not point out the existence of Carmen Resino's Penelope (Pen) in Ulises no vuelve. Written in 1974 and published in 1983 it falls outside the parameters of this study. Nonetheless, it is important to have this play - with its cowardly Ulysses who hides to avoid going to war and its rebellious Pen who is forced to be complicit in her husband's deception - in the back of our minds as we read about other Penelopes.

3. See Elisa Sanz's article for an excellent description of how the play is organized. 
timeless, mythical space $e^{4}$. Pascual, like Resino before her, chooses to split the character of Penelope, but does not reveal this plot twist until the end of the play. Las voces de Penélope moves back and forth from the mythical past to the present day, forcing the audience to sew together the threads of each woman's story. Gradually, the spectators become aware that the common thread shared by the characters is that they are all versions of Homer's Penelope. As John Gabriele observes, Pascual's three characters, «evolucionan independientemente, pero acaban por fundirse», creating what he calls a «concretización colectiva del Yo» (144).

In Penelope's first few scenes, she appears resigned to her fate. She sees herself as a victim of her circumstances and declares that she would rather die than keep on waiting: «no tengo razones para comer. No tengo razones para respirar. No tengo razones para vivir» (Pascual 2002, 313). By her fifth appearance in the play, she has reached the breaking point. She understands that she must either completely discard the myth that holds her hostage and refuse to be a victim or begrudgingly admit defeat and remain the obedient, mythical heroine. Penelope takes stock of the many important roles that she has assumed in her husband's absence: «madre, padre, reina, amiga, gobernante: todos los papeles para una única actriz», and she continues to name and then reject the one role that for years had been her destiny: «todos [los papeles] menos uno. Víctima no» (320). Penelope's empowerment is particularly apparent in the scene in which she greets a stranger, a man who has arrived in Ithaca after a long journey. It is Ulysses, but we never hear him speak; we only hear Penelope's side of the conversation. She tells the stranger that her absent husband is someone who «[...] vagamente me recuerda», but then stops herself saying, "pero no hablemos de ello. Son historias viejas» (321). Penelope will cast off this vieja historia and will replace it with a new myth of her own creation. By the end of the play, she recognizes that her waiting was not a submissive act, but rather an assertive act of defiance: «la espera es una forma de resistencia [...] la espera me hizo más fuerte, más segura y descreída [...] esperé a mí misma. Esta es mi verdadera historia» (331-332). Penelope has understood that she was trapped in someone else's story, playing a role that did not reflect her true identity.

La mujer is a modern Penelope and her character follows a similar trajectory to that of her mythical counterpart. Initially, she is portrayed as a passive and depressed victim incapable of moving on with her life after her boyfriend

4. From this point on I will refer to La mujer que espera as La mujer and La amiga de Penélope as La amiga. 
has left her. La mujer is paralyzed by self-doubt and can do nothing but wait for her lover to return. However, through the constant encouragement of her friend, La amiga, she eventually frees herself from this most destructive of roles. Her epiphany occurs during a delightful scene in which she opens her heart to a potted plant:

No he sabido... medir. Yo me he hundido entre tanto «ya veremos». Él se ahoga ante mis excesos y se desespera con mis carencias. (Pausa.) Será por eso que nunca he sabido regar las plantas. O las ahogo o se me secan. Hay que aprender a escuchar. Es una voz que está debajo de los pasos. Te dice: ahora. Y luego dice: basta. Si hubiera aprendido antes no serías tan pequeña. Habrías crecido más. (Pausa.) Yo también. (325-326)

She is now La mujer que esperó, and she explains to La amiga how she broke free of the myth: «aprendes a ver. Menos mitos, menos pedestales, menos héroes. Y también menos princesas de cuento» (329). Like Penelope, she rejects old stories and understands the vital need to create new ones.

La amiga is a more nuanced character. More upbeat and optimistic than Penelope and La mujer, she spends much of the play consoling La mujer and offering herself up as an example of a woman who would never wait for a man: «a mí eso no me pasaría nunca. A mí no. Yo lo tengo muy claro. Por ahí no paso. ¿Y por qué no le dejas? ¿Y por qué? Tú vales mucho más» (303). In fact, at times it seems that Pascual has put her on stage as a literary device, to prevent the play from falling into a series of monologues and to introduce some levity into the unfolding story. The engaged spectator can see beyond her formalistic function, though, and we do eventually discover that she too has spent many years waiting, waiting for her unfaithful and ungrateful lover to change. After finally ending this destructive relationship, she is now able to see the advantages of self-reliance: «cuando estás sola, observas más. Te fijas. Y el paisaje cambia» (324). She directs her newfound energy outwards into society, towards helping other women. For example, she dictates to La mujer a powerful treatise, bolstered by extensive statistical data, on the lack of women's rights in contemporary society that will be published by the local university. La amiga has rejected the myth of passivity and has become an active promoter of authentic female roles as well as a powerful voice of female resistance against the patriarchy. The Homeric motif of the passive woman who dutifully awaits her man's return is completely subverted in Las voces de Penélope. Ulysses' famous voyage has been hijacked. As La mujer observes: «A Ulises también le cambió el viaje. Pero esa es otra historia. Que le cuente él... Si quiere» (330). It is the women, not Ulysses, who make a voyage of discovery, albeit an internal one, into a deeper sense of self, a space that Penelope defines as «el diminuto 
espacio del ser y el estar» (331). All three versions of Penelope were waiting to discover themselves.

Polifonía, by Diana M. de Paco Serrano, offers another take on myth's innate power to address the retelling of women's stories. On stage in Polifonía are three of the most infamous female characters of Greek tragedy: Medea, Clytemnestra and Phaedra. The women awake to find themselves in a dark and gloomy grotto in a corner of the underworld (called «the prison» in the stage directions). The women, brought here by Penelope, demand to know where they are and why she is holding them there. Polifonía comprises fifteen short scenes: seven occur in the mythical present of the play, in the grotto, and the remaining eight are set somewhere in a vague time and space of memory. Unlike Pascual, whose only voices are female, de Paco also lets us hear the mythical heroes themselves. In the retrospective and elusive space of memory, we watch as Phaedra confronts Hippolytus and Theseus, Medea challenges and defies Jason, Clytemnestra battles with Agamemnon and Orestes, and Penelope faces first Telemachus and finally Ulysses. In these flashbacks, the men condemn themselves in their own words, ironically participating in the deconstruction of their own myths. As Floeck explains, «las heroínas arrancan las máscaras de la cara de sus esposos y lo que descubren detrás son instinto sexual, brutalidad, violencia, egoísmo y corrupción» $(2009,16)$. That De Paco «permits» these husbands and sons to present their own self-defense is important for at least three main reasons: it cleverly gives the spectators the impression that what they hear is unfiltered testimony; it casts ancient wives as reliable eye-witnesses; and it asks that we the audience be the judge.

One by one, the women awake and begin to remember their pasts. They retell their violent stories to one another in versions that seem more authentic than the «originals». Phaedra explains how she made the decision to commit suicide when it became clear that Hippolytus, selfish, immature and stubborn, would never return her love. Clytemnestra, rejecting the long-held notion that she killed Agamemnon to be with her lover Aegisthus, assertively defends her actions. She exclaims to Orestes: «Egisto no tenía nada que ver, no he actuado como mujer, no he sido yo quien ha obrado, sino la justicia vengadora» (84). Clytemnestra had to avenge her daughter Iphigenia's death. She could never forgive Agamemnon for sacrificing Iphigenia to the gods in exchange for political favors. Medea, too, will justify her act of violence, the murder of her children. We will listen as she explains to them the reasons for this terrible crime:

No, no se trata de venganza, se trata de ahorraros la amargura de un final inevitable, antes de que tengáis uso de razón, si llegáis a tenerlo. ¿Para qué 
dejaros navegar a la deriva, en medio de la tormenta, si el trayecto es terrorífico y el único final es el abismo? ¿Para qué esperar a que sean vuestros inocentes labios, ahora mudos, los que me supliquen una muerte sin dolor, sin conciencia? Yo sé lo que os espera porque ya he alcanzado el final. Os amo, os amo tanto que no puedo permitiros una pena que os consuma poco a poco. (67)

Medea insists that she acted out of pure, maternal compassion, telling Jason, «no ha sido una venganza, Jasón. No te la merecías. Yo no he pensado en ti, sino en ellos. No me arrepiento» (92). At last, all three women emerge from the spaces of memory, from these unexpected conversations with their husbands and sons, feeling validated and empowered because their versions of events have finally been put into the record, so to speak. But what about Penelope?

Penelope has listened patiently and with great interest to Medea, Phaedra and Clytemnestra, but it is only after their violent stories are retold and she has embroidered them on her tapestry that the other women may finally question why she is holding them captive. Phaedra asks her:

¿Y tú, Penélope? Solamente quedas tú. ¿Cómo termina tu historia? ¿Qué crimen has cometido? ¿Qué desgracias te han atormentado a lo largo de tu vida? Aunque lo niegues, ha de haber una razón que te haga estar junto a nosotras, ¿Qué es lo que te une a Clitemnestra, a Medea o a mí? Vamos, sé sincera. (93)

Penelope is adamant that she has nothing to hide: «me molesta vuestra insistencia [...], no ha habido ningún motivo de desasosiego en mi vida, excepto la ausencia de Ulises» (93). Having heard about Ulysses' adventures as she wandered around the world in exile, Medea knows more than Penelope realizes. Ulysses did return to Ithaca, but the man who returned, Medea explains, was «un hombre extraño, salvaje y bárbaro que ya no [le] amaba» (95). The real reason why Penelope has not completed her tapestry is that she killed Ulysses and even she finds it difficult to sanction this newest version of the oldest of myths. However, De Paco creates a sense of ethical comradery through these women's stories that at long last gives Penelope the strength to speak. Penelope's iconic tapestry, which in Polifonía was to be her husband's shroud, becomes instead a new female chronicle, a female-authored version of old stories, a new mythology. After Medea, Phaedra and Clytemnestra drape themselves at the end of the play in Penelope's cloth, now a symbol of female power, they clarify in unison: «Penélope era la parca. De ella dependía que la historia siguiera su ciclo natural o quedara suspendida y reinara el olvido» (106). Penelope's documentation of a new history, of a new myth, was only possible by denying her husband his mythical status and simultaneously being supported and inspired by other women who had managed to accomplish something similar. 
Both Pascual and De Paco use the story of the passive, obedient wife as a point of departure for their rewriting of myth. Pascual creates a fragmented Penelope and, as Harris concludes, «the presentation of the stories of three Penelopes in Pascual's work leads spectators to recognize that waiting on another [person] is not a natural part of female identity but a role that women have assumed» $(2003,6)$. Pascual's Penelopes show a path to self-knowledge and self-empowerment through the rejection of this destructively subservient gendered role. De Paco's Penelope has surrounded herself with women who, as Ragué-Arias notes, are «producto[s] de la violencia y del miedo» (727). Why? Because she too has committed a crime. She has destroyed both the man and his myth, and has put in their place a new myth, one written from a female perspective. Both dramatists hear the call of those silenced in the past and both will continue to deconstruct old paradigms, letting female voices come to the fore and offering modern audiences new, more sensitive ways to interpret old stories.

\section{RADICAL RETELLINGS: HISTORY, MYTH AND BEYOND}

In Variaciones sobre Rosa Parks (2007), Pascual gives voice to the African American Civil Rights icon. As the title indicates, this play does not proport to offer a definitive image of Rosa Parks. Instead, the word variaciones implies a more multifaceted and less simplistic approach to the historical figure. Variaciones sobre Rosa Parks is not just a straightforward retelling of historical events; it is a personal and authentic interior narrative that presents a nuanced image of Rosa Parks and her struggles to come to terms with her individual role in the history of her country. In a sense, it is a subtler exposition of the public/private dichotomy around which Resino and Romero's history plays were structured. Pascual's Rosa Parks was not born a queen, but her small act of personal courage, of unwitting social activism, forever altered the direction of racial history in the United States. Her existence as a private citizen ended the moment she refused to give up her seat and it is this transformation upon which Pascual plays to show how Rosa's bravery was never fully recognized or rewarded. On the contrary, Rosa is shown at the end of her life, living in poverty in Detroit. Like Romero and Resino before her, Pascual puts a famous historical figure on the stage and asks the audience if the price she paid at the personal level was worth her place in history.

Pascual anchors the play in the tension created between two dueling personalities. The protagonist is Rosa Parks, an old woman suffering from dementia who feels that her biography, written many years earlier, no longer tells the story of her life as she remembers it. «Ese libro ya no me sirve, ahora 
veo las cosas de otro modo» (31). Rosa narrates these elusive and shifting memories into a tape recorder, feeling compelled to document her life story before she dies. She is both helped and hindered in her storytelling by the antagonist, La sombra de Rosa Parks, her alter ego and the product of her dementia. ${ }^{5} \mathrm{La}$ sombra is adamant that she not be ignored: «si quieres contar tu historia vas a tener que contar conmigo. Vas a tener que aceptarme. Yo también formo parte de tu historia. Yo soy una parte de ti» (32). This ingenious splitting of the character of Rosa Parks into two at times contrasting halves allows Pascual to privilege dialogue over monologue and to offer competing recollections of the same autobiographical event.

The advantages of putting these two conflicting voices on stage are particularly clear in the scene in which Rosa and La sombra quote and discuss Sophocles' Antigone. The two characters are shown in a prison cell, recreating Rosa's incarceration after her arrest. Both women read Antigone together and use it to uphold their clashing positions. La sombra tells Rosa that it is time to stop protesting because things will not end well: « $i$ Quieres que tu vida sea una tragedia? Ismene, la que acepta los límites, sigue viva» (57). Rosa Parks rejects this defeatist attitude and refuses to give in: «Cómo se vive con eso? ¿Perder a los tuyos, perder tus derechos y no hacer nada? ¿Cómo se sale de esta cárcel? ¿Bajando la cabeza? ¿Una vez más?» (58). She knows that Antigone ends in tragedy but understands that «la libertad no es gratis» and that «no estamos exentos del dolor por nuestras acciones» (59). By discussing Antigone directly, Pascual chooses to foreground the parallels between the mythical and modern-day heroines who protested tyranny and defied the flawed laws of their times in defense of their moral values. It also tempts us to read the entire play as a contemporary dialogue between a reluctant and accidental Antigone (Rosa Parks) and her law-abiding sister, her dramatic foil, Ismene (La sombra). As Söderbäck observes, the character of Antigone is never far away when talking about civil disobedience:

Whenever and wherever civil liberties are endangered [...] when injustices take place - wherever she is needed, Antigone appears. And although the details and context may vary, certain elements of the story always remain the same: the lone individual fighting against state power, the kinship burial rites, and, interestingly, her status as a woman. Because whatever group or interest Antigone is brought in to defend [...] it is always as a woman [...] that she appears on stage. (3)

5. From this point on I will refer to this character as La sombra. 
Another scene that takes on more weight when viewed through the lens of Antigone is the one during which we witness the first and most detailed retellings of the events leading up to and including Rosa' refusal to move to the back of the bus. This is not an objective record of what happened, it is Rosa' interior monologue, performed, as on that fateful day, in the present tense, as she was riding home after a long day working as a seamstress (another modern-day Penelope, waiting, in this case, for basic human rights). La sombra punctuates Rosa's stream of consciousness with the words of two other characters in the story, the conductor and the racist white man who wants Rosa's seat. More than a metronomic back-and-forth, the dialogue at times wanders distractedly from the main subject to other, related stories. For example, La sombra recounts the brutal killing of Emmett Till, murdered for whistling at a white woman, and later Rosa interjects that she sees a young girl through the bus window and ponders what the future might hold for her: «me pregunto si ella disfrutará del final del 'iguales pero separados'. Me pregunto si ella podrá estudiar en una escuela sin segregaciones. Me pregunto si ella dejará de ver carteles que ponen 'for colored use'» (45). At length, the dialogue comes around to that moment when Rosa Parks was told to give up her seat. As she speaks, we feel with her the paralyzing weight of centuries of oppression:

No puedo moverme. No puedo, no quiero, no voy a hacerlo, me cargo sobre la silla, peso. De repente mi cuerpo pesa un quintal, peso como el autobús entero. De repente el mundo pesa menos que mi cuerpo y sé lo que arrastra. Arrastra los sueños de Emmett Till [...] arrastra el miedo de las noches de cruces, de sangre y caperuzas blancas [...] las vidas perdidas, los sueños rotos, los asesinatos impunes [...] los insultos de todos los que fueron atacados y agredidos. (50)

The interior narratives of this doubly-marginalized woman of color present her as a genuine human being who felt a range of powerful emotions we all can imagine, rather than reducing her to a paradoxically inimitable idol.

The second and third retellings of this story offer even darker accounts of events, now told in the past tense with the benefit of historical perspective and through the cruel filter of senile dementia. The immediate audience for these narrations is a group of foreign journalists who have tracked Rosa Parks down in Detroit and have come to interview her. Rosa offers one account of this interview while La sombra narrates a second. Rosa's version highlights the toll taken on her life by her decision. She was not only ostracized by white society for her disobedience, but also criticized and vilified by African Americans, for many suffered during the boycotts and civil unrest that unfolded in the wake of her arrest. Rosa explains how poorly she was treated: «los que habían aceptado 
su destino de esclavos me llamaban imbécil [...]. Se lo tiene merecido, estaba prohibido, ella se lo ha buscado, decían. Es mujer, negra y pobre, ¿quién se ha creído?, decían entre risas» (85). Her account is constantly criticized and undermined by La sombra who eventually silences her alter ego so that she may now «contar la historia a mi modo» (91). La sombra's version of the interview, with which the play closes, leaves us with the image of a poor and irritable elderly woman, hard of hearing and suffering from dementia. She seems tired of retelling her story and the audience finds itself weighing on one scale the value of her victory against all its consequences on the other. In Variaciones sobre Rosa Parks, Pascual shows just how fluid and ambivalent narrations of historical events can be. The precise allusion to Antigone, moreover, roots Pascual's criticism of twentieth-century racism, poverty and apathy in the very bedrock of ancient European theater. Her Rosa Parks becomes a monument to all who have defied unjust laws and, at the same time, an enduring ethical reminder for those whose suffering was thereby lessened.

Diana de Paco returns to the mythological world in 2016's short monologue, Casandra, to reappropriate the story of the daughter of King Priam and Queen Hecuba for the modern age. Cassandra has always been portrayed as a victim of her circumstances. As a young priestess and princess of Troy she spurned Apollo's advances, for which he spat in her mouth, condemning her to spend the rest of her life foreseeing the future and telling life-saving truths that no one would ever believe. As Virtudes Serrano explains, mythical tradition sees Cassandra as a "predictora no escuchada de la caída y de la destrucción de Troya, y como la joven esclavizada que correrá la misma suerte que Agamenón, su tiránico captor, sin haber tenido ella culpa alguna» (230). Diana de Paco has long been fascinated by Cassandra's tragic and compelling story and here, as if talking to Cassandra, she explains what drew her to write a play about this particular Greek heroine:

En realidad, tú tenías el poder, perdona Casandra, porque no te creí: eras sabia, dabas miedo, estabas maldita: una consecuencia que se convertirá en el destino inapelable de muchas heroínas griegas y que, desgraciadamente, es símbolo de la situación de muchas mujeres en la actualidad. (2017)

Diana de Paco's Cassandra will not passively accept this portrayal. She will offer another accounting of her life. She is, as we can see from this, her first statement, an emboldened and defiant heroine:

Yo soy Casandra. La hija, la hermana, la traidora, la puta, la loca. Casandra endiablada. Casandra molesta, incómoda para todos. Casandra rechazada. Casandra despreciada y azotada. Casandra viva. Casandra enamorada. 
Casandra poseída por Baco. Casandra que vio perecer Troya porque los hombres decidieron no creerla. Casandra maldita. $(2016,233)$

Naming and appropriating the labels and insults that have accompanied her through the ages, she negates the destructive power of even the worst of them. This is a potent one-woman show and we will not hear directly from any other character; the audience will hear everything through the ominous voice of Cassandra. Ironically then, the spectator is asked to believe the new version of events put forth by the cursed seer whom no one can believe. Will the audience believe her this time?

Cassandra sets her story in the time right after the fall of Troy and right before Agamemnon kidnaps her and takes her home as part of his spoils of war. Mixing stories of her past and present with those of her future, Cassandra reasserts her own identity by first re-appropriating negative descriptions and then by ruining the reputation of the god who destroyed her life. Apollo, the villain in Cassandra's story, is shown to be ambitious and cruel, blinded by lust, rejection and an insatiable need for power. She offers the audience this unflattering description:

El gran Apolo. El dios rechazado por una niña. El varón que no soporta ser ignorado por una mujer. El hombre divino que tiene que demostrar quién manda... El cobarde que castiga a la joven sacerdotisa por no querer ser su pareja, porque no lo soporta. [...] El equilibrado, sensible y justo Apolo. Apolo celoso y engreído. Apolo ambicioso y ciego de poder. Apolo dios inmortal que ordena el desastre. (233)

In this retelling, the events leading to the death and destruction of the Trojan War begin when Apollo curses the young prophetess. Cassandra tells the audience that it was Apollo who spread the false narratives that started the war. In short, what she tells us differs greatly from the original myth. In her account, there was no Helen of Troy. She was just a femme fatale invented by Apollo to provoke a war that satisfied his lust for violence. Paris was just another victim of Apollo's cruelty, used as a scapegoat to justify war. Paris and Cassandra, who were raised together but who were not biological siblings, were lovers, not Paris and Helen. Cassandra describes their relationship as tragic yet pure, as opposed to Paris' supposed relationship with Helen, which was based on adultery and deception. Before the war even starts, Paris dies while protecting Cassandra from the wrath of Apollo. Once Cassandra reveals the god's secret, that he is the master of the false narrative, she can free herself from the tremendous guilt she felt when her warnings and predictions went unheeded.

Casandra is unquestionably a tale of female empowerment, and like Pascual in Variaciones sobre Rosa Parks, De Paco also opens her work to broader social 
criticism, decrying the cruelty of war, the dangers inherent in spreading fake news and the hazards of apathy. Hecuba, Casandra's mother, plays a similar role to La sombra in Variaciones and to Ismene in Antigone. She is unable to defy her husband and therefore cannot protect her children. Hecuba choses to do nothing: «mi madre lloraba en silencio porque creía que era lo mejor para todos. Mamá, siempre has llorado tus verdades en lugar de decirlas» (234). Cassandra will not be silenced and, although she understands her mother's motivations, she cannot live her life without fighting for what she knows to be true. Cassandra asks her mother towards the end of the play: «iFingir que no se cree la verdad es malo, madre? ¿Cerrar los ojos nos hace culpables?» (239). For Cassandra, taking no action against injustice is not an option. She, like the women of Polifonia, wants to set the record straight and place blame in the correct place, in this case, on a god. By defying Apollo, she is challenging the norms of her society and encouraging other women to do the same. Through the figure of Cassandra and her echoes of Antigone, Diana de Paco invites her spectators to open their eyes to injustice, to speak out against it and to defy those who wish to keep women subservient.

\section{CONCLUSIONS}

Myth and history, narrative bastions of male power, have perhaps unexpectedly proven themselves to be fertile areas for female writers. All the dramatists considered here have «rescued» famous or infamous women from sometimes millennia-old, male-dominated chronicles. Retelling their stories from much more «private» points of view, these figures emerge from the penumbra of their public, male-authored roles. In traditional narratives, the protagonism of female characters is permitted only if it ennobles or improves the legends of their husbands or sons. In these contemporary woman-authored plays of democratic Spain, however, well-known female figures discard the masks made for them by others and take center stage to tell their own stories. Moving away from a linear realism, the dramatists present their stories out of sequence, forcing the audience to be an active participant in the unfolding events. Sometimes, they split their characters into egos and alter egos, opening their plays to more than a single interpretation of a particular character. Other times, interior monologues are used to great effect, taking us through the mental processes behind momentous decisions. Passivity and apathy are shown to be behaviors taught to women by the self-perpetuating patriarchy. The retelling of their resistance seeks to write three-dimensional women back into two-dimensional history and myth. This is not merely a compensatory technique, however. Whether the spotlight is shining on an English queen, a Penelope or a Sophoclean Rosa 
Parks, it is always a woman's voice that is speaking to us. This is another step toward the creation, better late than never, of the female role model who is missing from traditional history and myth. Looking back over the last thirty years of women's theater from the vantage point of 2017, we witness a movement away from a simple revision of women's roles. Instead, more and more frequently, these authors use the narrative paradigms of history and myth as a point of departure to address broader issues such as poverty, human rights and racism. Such universal themes are the very territory of myth and by presenting them from a female perspective, the dramatists challenge their audiences to look beyond one «authoritative» narrative, beyond a single, male-inscribed point of view, to a more pertinent and complete vision of the problems facing the world outside the theater.

\section{WORKS CITED}

Floeck, Wilfried. «¿Entre posmodernidad y compromiso social? El teatro español a finales del siglo XX». Teatro y sociedad en la España actual. Eds. Wilfried Floeck and María Francesca Vilches de Frutos. Frankfurt am Main: Vervuert, 2004. 189-207.

Floeck, Wilfried. «Introducción a Polifonía». In Diana de Paco Serrano. Polifonía. Murcia: Universidad de Murcia, 2009. 9-21.

Gabriele, John P. «Personajes descentrados y realidades fragmentadas: aspectos posmodernos de la dramaturgia de Itziar Pascual». Hecho teatral 3 (2003): 135-150.

Harris, Carolyn J. «Isabel y Juana: protagonistas históricas del teatro de Concha Romero». Estreno 19.1 (1993): 26-28.

Harris, Carolyn J. «Myth, Role, and Resistance in Itziar Pascual's Las voces de Penélope». Gestos 36 (2003): 91-101.

Paco Serrano, Diana M. de. «La reescritura de las heroínas griegas desde la perspectiva de las dramaturgas españolas contemporáneas». Hecho teatral 3 (2003): 89-111.

Paco Serrano, Diana M. de. Casandra. Casandras. Madrid: Esperpento Ediciones Teatrales, 2016. 232-240.

Paco Serrano, Diana M. de. Polifonía. Casandras. Madrid: Esperpento Ediciones Teatrales, 2016. 40-106.

Paco Serrano, Diana M. de. «CASANDRAS. ¿Por qué Casandra?» El Kiosko Teatral 1 (2017) <http://www.aat.es/elkioscoteatral/las-puertas-del-drama/dramaextra-1/casandras-por-que-casandra>, consulted 10-08-2017.

Pascual, Itziar. Las voces de Penélope. Ni Ariadnas ni Penélopes: quince escritoras españolas para el siglo veintiuno. Ed. Carmen Estévez. Madrid: Castalia, 2002. 295-332.

Feminismo/s 30, diciembre 2017, pp. 47-68 
Pascual, Itziar. Variaciones sobre Rosa Parks. Madrid: Universidad Complutense, 2007.

Podol, Peter L. «Three Stages in the Life of Isabel: Plays by Alberto Miralles, Manuel Martínez Mediero and Concha Romero». Estreno 16.1 (1988): 28-31.

Ragué-Arías, María José. Review of Diana de Paco Serrano. Polifonía. Murcia: Universidad de Murcia, 2009. Signa 21 (2012): 725-28.

Resino, Carmen. Ulises no vuelve. Madrid: Centro Español del Instituto Internacional del Teatro, 1983.

Resino, Carmen. Los mercaderes de la belleza. Los eróticos sueños de Isabel Tudor. Madrid: Fundamentos, 1992.

Romero, Concha. Las bodas de una princesa. Madrid: Lucerna, 1988.

Romero, Concha. Juego de reinas o razón de estado. Madrid: Editorial J. García Verdugo, 1989.

Sanz, Elisa. «Las voces de Penélope: Revisión contemporánea de un mito». Parnaseo. ciber-paseo por la literature. <http://parnaseo.uv.es/Ars/Autores/Pascual/obras/ elisa_sanz.pdf>, consulted 08-08-2017.

Serrano, Virtudes. «Casandra, otra voz para el presente». Casandras. Madrid: Esperpento Ediciones Teatrales, 2016. 230-231.

Söderbäck, Fanny. Feminist Readings of Antigone. Albany: State University of New York Press, 2010. 